\title{
A anatomia do homem é a chave da anatomia do macaco: A dialética em Vigotski e em Marx e a questão do saber objetivo na educação escolar
}

Newton Duarte*

O conhecimento é o processo pelo qual o pensamento se aproxima infinita e eternamente do objeto. O reflexo da Natureza no pensamento humano deve ser compreendido não de maneira "morta", não "abstratamente", não sem movimento,

não sem contradição, mas sim no processo eterno do movimento, do nascimento das contradições e sua resolução.

(Lénine, 1975, p. 123)

\begin{abstract}
RESUMO: Vigotski, em seu "Manuscrito de 1929" afirma que a relação filogênese-ontogênese no desenvolvimento orgânico é distinta da mesma relação no desenvolvimento cultural: enquanto que o embrião humano se desenvolve sem interagir com o organismo adulto, o desenvolvimento cultural da criança só ocorre por meio da interação com o adulto, isto é, com o ser mais desenvolvido. Partindo dessa afirmação, o artigo analisa as relações entre a dialética em Vigotski e em Marx, apoiando-se na reflexão metodológica e epistemológica desenvolvida por Marx no texto em que afirmou que "a anatomia do homem é a chave da anatomia do macaco". O artigo conclui com a defesa da tese de que a psicologia vigotskiana fornece apoio a uma pedagogia que valorize a transmissão das formas mais desenvolvidas do saber objetivo produzido pela humanidade.
\end{abstract}

Palavras-chave: Vigotski, Marx, dialética, epistemologia

* Livre-docente em Psicologia da Educação, professor da UNESP, campus de Araraquara. 


\section{A dialética em Vigotski}

"Não quero saber de graça, escolhendo um par de citações, o que é a psique, o que desejo é aprender na globalidade do método de Marx, como se constrói a ciência, como enfocar a análise da psique."1 Vigotski fez essa afirmação como parte de sua argumentação quanto à necessidade de uma teoria geral da psicologia, uma psicologia geral, que possibilitasse a construção de uma psicologia marxista, superando a crise existente nesse campo da ciência, crise essa caracterizada pela contradição entre, por um lado, o acúmulo de dados obtidos através das pesquisas empíricas e, por outro, a total fragmentação da psicologia em uma grande quantidade de correntes teóricas construídas com base em pressupostos muito pouco consistentes.

A construção da psicologia marxista era vista por Vigotski não como o surgimento de mais uma entre as correntes da psicologia, mas sim como o processo de construção de uma psicologia verdadeiramente científica. Essa psicologia científica não seria, entretanto, construída através da justaposição de citações extraídas dos clássicos do marxismo a dados de pesquisas empíricas realizadas por meio de métodos fundamentados em pressupostos filosóficos contraditórios ao marxismo. Vigotski entendia ser necessária uma teoria que realizasse a mediação entre o materialismo dialético, enquanto filosofia de máximo grau de abrangência e universalidade, e os estudos sobre os fenômenos psíquicos concretos. Vigotski fazia um paralelo entre essa teoria psicológica mediadora e o materialismo histórico, pois este também tem o papel de estabelecer as necessárias mediações entre o materialismo dialético e a análise das questões concretas, neste caso, as questões concretas da história das sociedades e de cada formação social específica, como o capitalismo, estudado de forma científica por Karl Marx. Por essa razão Vigotski afirmou ser necessária uma teoria que desempenhasse para a psicologia o mesmo papel que a obra $O$ capital de Karl Marx desempenha para a análise do capitalismo.

É nesse contexto que Vigotski criticou aqueles que pensavam estar construindo uma psicologia marxista justapondo dados psicológicos empíricos a citações dos clássicos do marxismo sem questionar, entretanto, os pressupostos contidos na análise dos dados e nos métodos de obtenção dos mesmos. Vigotski também criticou as tentativas de justaposição do marxismo a teorias psicológicas estranhas ao universo marxista e incompatíveis com o mesmo, tentativas essas que seriam operadas através de dois procedimentos: 
Se este primeiro procedimento de importação de idéias alheias de uma escola a outra lembra a anexação de um território alheio, o segundo procedimento de associação de idéias alheias se assemelha a um tratado de aliança entre dois países, mediante o qual nenhum dos dois perde sua independência, porém chegam ao acordo de atuarem conjuntamente, partindo da comunhão de interesses. Este procedimento é ao qual se costuma recorrer quando se quer associar o marxismo e a psicologia freudiana. Neste caso se utiliza o método que por analogia com a geometria poderíamos denominar "método de superposição lógica de conceitos". Define-se o sistema marxista como monista, materialista, dialético, etc. Depois se estabelece o monismo, o materialismo, etc. do sistema freudiano; ao superpor os conceitos, estes coincidem, e se declaram unidos os sistemas. Mediante um procedimento elementar eliminam-se contradições gritantes, bruscas, que saltam à vista, excluindo-as simplesmente do sistema, considerando-as exageradas, etc. É assim que se dessexualiza o freudismo, porque o pansexualismo não concorda de modo algum com a filosofia de Marx. "Bom", dizem-nos, "admitamos o freudismo sem os postulados da sexualidade". Mas ocorre que esses postulados constituem precisamente o nervo, a alma, o centro de todo o sistema. É cabível aceitar um sistema sem seu centro? Porque a psicologia freudiana sem o postulado da natureza sexual do inconsciente é o mesmo que o cristianismo sem Cristo e o budismo com Alá ${ }^{2}$. (Vygotsky 1991, pp. 296-297)

Ao contrário daqueles que, atualmente, identificam como dogmatismo a adoção firme e explícita de uma corrente teórica e, por conseqüência, identificam como abertura de espírito a ausência de posicionamento firme e explícito, Vigotski entendia que a clareza quanto aos fundamentos centrais do marxismo e a adoção firme desses fundamentos é que poderia possibilitar aos psicólogos marxistas não se fecharem às questões formuladas por correntes não marxistas da psicologia.

No enfoque não-crítico cada um vê o que quer e não o que é: um marxista encontra na psicanálise o monismo, o materialismo ou a dialética que não aparecem nela [...] O que não significa, naturalmente, de modo algum que os marxistas não devam estudar o inconsciente pelo mero fato de que as concepções principais de Freud contradigam o materialismo dialético. Pelo contrário, precisamente porque a psicanálise estuda seu objeto com base em meios impró- 
prios, é necessário conquistá-lo para o marxismo, estudá-lo empregando os meios da verdadeira metodologia ${ }^{3}$. (Vygotsky 1991, p. 302)

Quando Vigotski afirmava querer apreender da globalidade do método de Marx como se constrói a ciência, isso não pode, portanto, ser interpretado num sentido pragmático, bastante corrente nos dias de hoje quando é focalizada a questão do método em educação (os métodos de pesquisa e os métodos de ensino), como se Vigotski pretendesse adotar de Marx apenas aquilo que fosse imediatamente útil à pesquisa no campo da psicologia. Vigotski pretendia fundamentar em Marx a construção da psicologia, pretendia construir uma psicologia marxista e para isso se fazia imprescindível a adoção do método de Marx em sua globalidade. Não há margem para ecletismos nem para justaposições que desconsiderem o núcleo da concepção marxista de ser humano, de sociedade e de história. Nesse sentido, nos dias de hoje não é demais ressaltar que Vigotski entendia que o próprio desenvolvimento da psicologia enquanto ciência está condicionado ao avanço do processo de construção de uma sociedade socialista:

Nossa ciência não podia nem pode desenvolver-se na velha sociedade $^{4}$ [a sociedade capitalista]. Ser donos da verdade sobre a pessoa e da própria pessoa é impossível enquanto a humanidade não for dona da verdade sobre a sociedade e da própria sociedade. Pelo contrário, na nova sociedade [a sociedade socialista], nossa ciência se encontrará no centro da vida. "O salto do reino da necessidade ao reino da liberdade" formulará inevitavelmente a questão do domínio de nosso próprio ser, de subordiná-lo a nós mesmos. (1991, p. 406)

Em outros trabalhos temos defendido reiteradamente a necessidade da obra de Vigotski ser lida com base nesse universo de referência marxista e socialista (Duarte 1996 e 2000). Neste artigo focalizaremos especificamente a questão das relações entre o pensamento vigotskiano e o método dialético em Marx. O "Manuscrito de 1929" de Lev Vigotski, traduzido e publicado em português pela primeira vez neste número especial da revista Educação \& Sociedade, apresenta várias passagens a partir das quais pode ser abordado o tema deste artigo. Obviamente que esse manuscrito, para ser devidamente compreendido, precisa ser ana- 
lisado à luz do restante da obra vigotskiana. É com esse espírito que tomaremos como ponto de partida uma passagem do citado manuscrito:

\begin{abstract}
Mais freqüentemente, o deslocamento de estruturas do exterior para o interior: uma relação de ontogenia e filogenia diferente da ocorrida no desenvolvimento orgânico. No último caso, a filogenia é potencial e é repetida na ontogenia; no primeiro caso existe uma interação real entre ontogenia e filogenia: o homem não é necessário como um biotipo: para o feto ou embrião humano se desenvolver no útero da mãe, não é preciso que ele interaja com um biotipo maduro. No desenvolvimento cultural, essa interação constitui a principal força impulsionadora de todo o desenvolvimento (aritmética, fala etc. adulta e infantil). (Vygotsky 1989, p. 59, tradução de Enid A. Dobránsky)
\end{abstract}

Como dissemos, esse manuscrito precisa ser interpretado à luz dos demais trabalhos de Vigotski, para que possa ser percebida a importância de um trecho como o destacado acima. Nesse trecho, Vigotski faz uma diferenciação entre a relação filogênese-ontogênese no desenvolvimento orgânico do indivíduo humano e essa mesma relação no desenvolvimento cultural, social desse indivíduo. O desenvolvimento sócio-cultural do indivíduo é o desenvolvimento de um indivíduo histórico, portanto situado na história social humana. Para que esse desenvolvimento ocorra é necessário que o indivíduo se aproprie dos produtos culturais, tanto aqueles da cultura material como aqueles da cultura intelectual. Essa apropriação da cultura pela criança é mediatizada pelos adultos que já se apropriaram da mesma cultura, isto é, o processo de apropriação é um processo mediatizado, um processo que exige a interação entre adultos e crianças (Cf. Leontiev 1978). Vigotski, no trecho citado, é bem claro ao afirmar que essa interação é a principal força impulsionadora de todo o desenvolvimento. A transmissão pelo adulto à criança, da cultura construída na história social humana, não é concebida na psicologia vigotskiana apenas como um dos fatores do desenvolvimento, ela é considerada o fator determinante, principal. Nota-se aí a grande distância existente entre a concepção de desenvolvimento em Vigotski e em Piaget. Este entendia que a "transmissão social" seria um dos três fatores clássicos do desenvolvimento, juntamente com a hereditariedade e o meio físico (Piaget 1994, pp. 89-90); a esses três fatores deveria ser acrescentado um quarto fator, o processo de equilíbrio por auto-regulações, "mais geral que os três primeiros", que poderia "ser analisado de forma relativamente autônoma". Ao considerar esse processo 
como o motor espontâneo do desenvolvimento intelectual, motor que não seria determinado pela transmissão social, mas, ao contrário, seria aquele que determinaria a própria possibilidade de algum êxito nessa transmissão, Piaget acaba por transformar o social em algo externo ao desenvolvimento do indivíduo ou, na melhor das hipóteses, em um componente secundário desse desenvolvimento.

Na passagem do manuscrito por nós citada neste artigo, Vigotski ressalta a importância da interação entre o ser em desenvolvimento, isto é, o ser menos desenvolvido, e o ser adulto, o ser mais desenvolvido. Afirma o psicólogo soviético que essa interação não é necessária para o desenvolvimento do embrião humano, mas ela é fundamental para o desenvolvimento cultural do indivíduo humano. Isso remete a um aspecto do método dialético de Marx que é adotado por Vigotski, aspecto esse sintetizado na famosa metáfora de Marx que adotamos como título deste artigo, a de que a anatomia do homem é a chave da anatomia do macaco. No texto "O significado histórico da crise da psicologia: uma investigação metodológica", abordado por Vigotski no que se refere ao método de investigação em psicologia. O psicólogo soviético defende a utilização, pela pesquisa psicológica, daquilo que ele chamava de "método inverso", isto é, o estudo da essência de determinado fenômeno através da análise da forma mais desenvolvida alcançada por tal fenômeno. Por sua vez, a essência do fenômeno na sua forma mais desenvolvida não se apresenta ao pesquisador de forma imediata, mas sim de maneira mediatizada e essa mediação é realizada pelo processo de análise, o qual trabalha com abstrações. Trata-se do método dialético de apropriação do concreto pelo pensamento científico através da mediação do abstrato. A análise seria um momento do processo de conhecimento, necessário à compreensão da realidade investigada em seu todo concreto. Vigotski adota assim, da dialética de Marx, dois princípios para a construção do conhecimento científico em psicologia: a abstração e a análise da forma mais desenvolvida.

Vejamos o que escreveu Vigotski sobre essa questão metodológica:

Tratei de introduzir a aplicação deste método pessoalmente na psicologia consciente, tentando deduzir as leis da psicologia da arte mediante a análise de uma fábula, um romance e uma tragédia. Parti para isso da idéia de que as formas mais desenvolvidas da arte são a chave das formas atrasadas, como a anatomia do homem o é em relação à dos macacos e não ao contrário. Faço afirmações, ademais, sobre toda a arte e não com- 
provo todavia minhas conclusões na música, na pintura etc. Ainda mais: não as comprovo sequer em todas ou na maioria das variedades de literatura; tomo somente um romance, uma tragédia. Com que direito? Não estudei as fábulas nem as tragédias e menos ainda uma fábula dada e uma tragédia dada. Estudei nelas o que constitui a base de toda a arte: a natureza e o mecanismo da reação estética. Apoiei-me nos elementos gerais da forma e do material inerentes a toda a arte. Escolhi para a análise a fábula, o romance e a tragédia mais difíceis, precisamente aquelas nas quais são especialmente patentes as leis gerais: selecionei os monstros dentro das tragédias etc. Essa análise pressupõe fazer abstração dos traços concretos da fábula como um gênero determinado para concentrar o esforço na essência da reação estética. Por isso não digo nada da fábula como tal. $E$ o próprio subtítulo "Análise da reação estética" indica que a finalidade da investigação não consiste na exposição sistemática da doutrina psicológica da arte em todo seu volume e amplitude (todas as variedades da arte, todos os problemas etc.) nem sequer a investigação indutiva de uma série determinada de fatos, mas sim justamente a análise dos processos em sua essência. (Vygotsky 1991, pp. 374-375)

Nessa passagem, Vigotski refere-se a seu trabalho Psicologia da $\operatorname{arte}^{6}$ (Vygotsky 1972). Como é possível notar, a intenção de Vigotski nessa investigação sobre a psicologia da arte foi descobrir a essência da reação estética. Para isso ele recorreu em primeiro lugar ao método da análise, buscando detectar aquilo que constituiria a unidade mais essencial da reação estética, independentemente do fato dessa reação estética nunca aparecer de forma pura, abstrata, mas sempre sob formas concretas, dependentes tanto do tipo de obra de arte como das relações que se estabelecem entre um indivíduo concreto e uma obra de arte concreta. Além de recorrer ao método da abstração, Vigotski recorreu também ao método inverso, isto é, buscou analisar formas desenvolvidas de arte, pressupondo que seu estudo revelaria aspectos válidos também para formas menos desenvolvidas, sendo que o inverso não seria necessariamente verdadeiro. Note-se que a utilização do método inverso por Vigotski implica que ele considerava existirem formas inferiores e formas superiores de arte. Por certo isso soa estranho àqueles que busquem em Vigotski apoio para posições pedagógicas que postulam um multiculturalismo relativista para o qual não há sentido em afirmar que existam saberes mais desenvolvidos que outros, mas apenas que existem diferentes saberes. 
De nossa parte, que não compartilhamos em absoluto com esse tipo de relativismo, consideramos positivo que Vigotski não deixe dúvidas quanto ao fato de considerar que existem formas inferiores e superiores de arte. Aliás, isso nos parece bastante coerente com as investigações realizadas por Vigotski acerca das relações, no desenvolvimento do pensamento infantil, entre os conceitos cotidianos (também chamados por Vigotski de conceitos espontâneos ou conceitos empíricos) e os conceitos científicos. No livro Pensamento e linguagem, publicado em seu texto integral no volume II das Obras Escolhidas ${ }^{7}$ de Vigotski, o autor nos mostra que os conceitos científicos, ao serem ensinados à criança através da educação escolar, superam por incorporação os conceitos cotidianos, ao mesmo tempo que a aprendizagem daqueles ocorre sobre a base da formação destes:

O sistema primário, surgido na esfera dos conceitos científicos se transfere estruturalmente ao campo dos conceitos cotidianos, reestruturando-os, modificando sua natureza interna a partir de cima. Um e outro (a dependência dos conceitos científicos dos espontâneos e a influência recíproca dos primeiros nos segundos) se depreende dessa relação específica que existe entre o conceito científico e o objeto, a qual se caracteriza, como dissemos, por estar mediada através de outro conceito e, por conseguinte, incluir, por sua vez, junto com a relação para com o objeto, a relação com outro conceito, isto é, os elementos primários do sistema de conceitos. Portanto, o conceito científico, pelo fato de ser científico, por sua própria natureza, pressupõe um determinado lugar dentro do sistema dos conceitos, o qual determina sua relação com outros conceitos. A essência de qualquer conceito científico é definida por Marx de um modo muito profundo: "se a forma de manifestação e a essência das coisas coincidissem, toda ciência seria supérflua" [...] Esse é o quid do conceito científico. Seria supérfluo se refletisse o objeto em sua manifestação externa como conceito empírico. (Vygotsky 1993, p. 216)

Tanto no que se refere à arte, como no que se refere à relação entre conceitos cotidianos e conceitos científicos, Vigotski era explícito quanto ao que considerava superior, mais desenvolvido. Ora, essa é uma questão fundamental para os educadores pois ela toca nas questões do que ensinar, a quem ensinar, quando ensinar, como ensinar e por que ensinar. 
Retomando a questão metodológica e epistemológica em Vigotski, é importante assinalar que, ao defender a necessidade da análise para compreensão de determinado fenômeno psicológico, esse pesquisador diferenciava claramente a análise que se reduz à descrição do mais imediatamente visível e a análise que vai além das aparências:

Na realidade, a psicologia nos ensina a cada passo que duas ações podem ocorrer por sua aparência externa de maneira similar e serem, todavia, muito distintas por sua origem, essência e natureza. Em casos assim são necessários meios especiais de análise científica por detrás da semelhança exterior às diferenças internas. Nesses casos resulta necessário, à análise científica, o saber descobrir sob o aspecto externo do processo seu conteúdo interno, sua natureza e sua origem. Toda a dificuldade da análise científica radica no fato da essência dos objetos, isto é, sua autêntica e verdadeira correlação não coincidir diretamente com a forma de suas manifestações externas e por isso é preciso analisar os processos; é preciso descobrir por esse meio a verdadeira relação que subjaz nesses processos por detrás da forma exterior de suas manifestações. Desvelar essas relações é a missão que há de cumprir a análise. A autêntica análise científica na psicologia se diferencia radicalmente da análise subjetiva, introspectiva, que por sua própria natureza não é capaz de superar os limites da descrição pura. A partir de nosso ponto de vista, somente é possível a análise de caráter objetivo já que não se trata de revelar o que nos parece o fenômeno observado, mas simo que ele é na realidade. (Vygotsky 1995, p. 104, grifo nosso)

Assim, a defesa por Vigotski do método da análise e da necessidade da mediação das abstrações traduz sua compreensão dialética e materialista do conhecimento científico. Dialética porque a apreensão da realidade pelo pensamento não se realiza de forma imediata, pelo contato direto com as manifestações mais aparentes da realidade. Há que se desenvolver todo um complexo de mediações teóricas extremamente abstratas para se chegar à essência do real. Materialista porque Vigotski não compartilhava de qualquer tipo de idealismo ou de subjetivismo quando defendia a necessidade da mediação do abstrato. O conhecimento construído pelo pensamento científico a partir da mediação do abstrato não é uma construção arbitrária da mente, não é o que o fenômeno parece ser ao indivíduo, esse conhecimento é a captação, pelo pensamento, da essência da realidade objetiva, é reflexo dessa realidade: 
Este novo enfoque nos mostra que a realidade determina nossa experiência; que a realidade determina o objeto da ciência e seu método e que é totalmente impossível estudar os conceitos de qualquer ciência prescindindo das realidades representadas por esses conceitos. F. Engels assinala repetidas vezes que para a lógica dialética a metodologia da ciência é o reflexo da metodologia da realidade. (Vygotsky 1991, p. 289)

Essa epistemologia materialista e dialética de Vigotski está em perfeita consonância com a dialética presente na obra de Marx. A dialética marxiana também se apoia no princípio de que a abstração é uma mediação indispensável pela qual a ciência chega à essência da realidade concreta. Marx, no prefácio da primeira edição de $O$ capital, assinalou que o entendimento da parte inicial voltada para a análise da mercadoria seria a de maior dificuldade para o leitor, mas assinala também que o enfrentamento de tal dificuldade seria necessário para que, por meio da mediação desse processo de análise abstrata, pudesse o leitor chegar à compreensão do modo de produção capitalista enquanto totalidade concreta:

A forma do valor, cuja figura acabada é a forma do dinheiro, é muito simples e vazia de conteúdo. Mesmo assim, o espírito humano tem procurado fundamentá-la em vão há mais de 2000 anos, enquanto, por outro lado, teve êxito, ao menos aproximado, a análise de formas muito mais complicadas e repletas de conteúdo. Por quê? Porque o corpo desenvolvido é mais fácil de estudar do que a célula do corpo. Além disso, na análise das formas econômicas não podem servir nem o microscópio nem reagentes químicos. $A$ faculdade de abstrair deve substituir ambos. Para a sociedade burguesa, a forma celular da economia é a forma de mercadoria do produto do trabalho ou a forma do valor da mercadoria. Para o leigo, a análise parece perder-se em pedantismo. Trata-se, efetivamente, de pedantismo, mas daquele de que se ocupa a anatomia microscópica. (Marx 1983, pp. 12-13)

Vigotski citava com freqüência essa passagem de Marx para defender a importância do "método da abstração" também na psicologia, assim como em toda a ciência. Por essa razão Vigotski entendia que se alguém pudesse encontrar a "célula" da psicologia, assim como Marx 
havia encontrado a célula do capitalismo, encontraria a chave de toda a psicologia (Vygotsky 1991, p. 377).

Tem sido já bastante comentado pelos estudiosos de Vigotski que no capítulo primeiro do livro Pensamento e linguagem, intitulado "O problema e o método de investigação" (Vygotsky 1993, pp. 15-26), Vigotski critica os pesquisadores em psicologia que buscam compreender os fenômenos psicológicos a partir do isolamento dos elementos mais simples desses fenômenos e da análise desses elementos em si e por si mesmos:

Cremos que substituir esse tipo de análise por outro muito diferente é um passo decisivo e crítico para a teoria do pensamento e da linguagem. Teria de ser uma análise que segmentasse o complexo conjunto em unidades. Por unidade entendemos o resultado da análise que, diferentemente dos elementos, goza de todas as propriedades fundamentais características do conjunto e constitui uma parte viva e indivisível da totalidade. Não é a fórmula química da água senão o estudo das moléculas e do movimento molecular o que constitui a chave da explicação das propriedades definidoras da água. Assim, a célula viva, que conserva todas as propriedades fundamentais da vida, definidora dos organismos vivos, é a verdadeira unidade da análise biológica (Vygotsky 1993, pp. 19-20)

Em substituição ao método da análise dos elementos, Vigotski propunha o emprego do método da análise das unidades. Entretanto, convém observar que a análise das unidades não substitui a compreensão da totalidade. A unidade, ainda que conserve as características essenciais da totalidade (a mercadoria contém as características essenciais do capitalismo), ela é objetivamente parte de um todo e o processo de conhecimento deve caminhar da análise abstrata dessa unidade para a síntese concreta do todo no pensamento. Essa observação é particularmente importante nos dias atuais, quando, por influência do ideário pós-moderno, existe sempre uma forte tendência a se abandonar a tentativa de compreensão do todo.

Para esclarecer ainda mais essas múltiplas e complexas relações próprias da dialética existente tanto na obra de Vigotski como na de Marx, passaremos à análise, no próximo item deste artigo, da exposição de Marx acerca do método dialético. Essa análise fora escrita como Introdução para a Crítica da Economia Política (Marx 1978, pp. 127-257). Quan- 
do da publicação do livro, porém, Marx decidiu suprimi-la por concluir que "toda antecipação perturbaria os resultados ainda por provar" e que o leitor que se dispusesse a seguir seu pensamento teria de "se decidir a ascender do particular para o geral".

Em Duarte (2000, pp. 128-148), analisamos essa Introdução escrita por Marx, no que se refere à crítica, nela contida, à naturalização do social pela economia política burguesa. No próximo item deste artigo, nós nos deteremos numa questão que naquele trabalho não abordarmos, a questão do método dialético.

\section{A dialética em Marx}

Em "O método da Economia Política", Marx (1978, pp. 116-123) estabelece relações entre o todo e as partes, entre o abstrato e o concreto e entre o lógico e o histórico, tanto no que se refere ao pensamento (as relações entre as categorias enquanto questão lógico-epistemológica), como no que se refere à realidade histórico-social (as relações entre as categorias enquanto questão relativa ao ser, isto é, questão ontológica).

Marx inicia sua análise mostrando que, no terreno da ciência, no caso, da economia política, ao estudar-se uma determinada realidade, por exemplo, um país, o procedimento mais correto aparentemente seria começar pelo real, pelo concreto. Mas Marx mostra que existe aí um equívoco, pois o pensamento não pode se apropriar do concreto de forma imediata, não pode reproduzi-lo através do contato direto. O contato direto produz no pensamento uma "representação caótica do todo", que não pode ser considerada como efetiva apropriação da realidade pelo pensamento. Marx (1978, p. 116), assim expõe essa questão:

Quando estudamos um dado país do ponto de vista da Economia Política, começamos por sua população, sua divisão em classes, sua repartição entre cidades e campo, a orla marítima; os diferentes ramos da produção, a exportação e a importação, a produção e o consumo anuais, os preços das mercadorias, etc. Parece que $o$ correto é começar pelo real e pelo concreto, que é a pressuposição prévia e efetiva; assim, em Economia, por exemplo, começar-se-ia pela população, que é a base e o sujeito do ato social de produção como um todo. No entanto, graças a uma observação mais atenta, 
tomamos o conhecimento de que isso é falso. A população é uma abstração, se desprezarmos, por exemplo, as classes que a compõem. Por seu lado, estas classes são uma palavra vazia de sentido se ignorarmos os elementos em que repousam, por exemplo: o trabalho assalariado, o capital, etc. Estes supõem a troca, a divisão do trabalho, os preços, etc. O capital, por exemplo, sem o trabalho assalariado, sem o valor, sem o dinheiro, sem o preço, etc., não é nada. Assim, se começássemos pela população, teríamos uma representação caótica do todo, e através de uma determinação mais precisa, através de uma análise, chegaríamos a conceitos cada vez mais simples; do concreto idealizado passaríamos a abstrações cada vez mais tênues até atingirmos as determinações as mais simples. Chegados a esse ponto, teríamos que voltar a fazer a viagem de modo inverso, até dar de novo com a população, mas desta vez não com uma representação caótica de um todo, porém com uma rica totalidade de determinações e relações diversas.

Qual o significado da afirmação: "a população é uma abstração, se desprezarmos, por exemplo, as classes que a compõem"? Lembremos que Marx está se referindo-se à análise econômica de um país. Nesse caso, tomar como ponto de partida a população, isto é, a população em geral, cujo único elemento comum a todos os membros dessa população é o fato de pertencerem ao mesmo país, pouco ou nada diz sobre a realidade econômica desse país se não for levado em consideração que essa população não é homogênea, mas composta por classes sociais. $O$ termo abstração aparece aí como sinônimo de uma idéia que não corresponde à complexidade do conteúdo da realidade. Por essa razão, começar pela população significa partir de uma "representação caótica do todo". Se essa representação inicial não é capaz de traduzir adequadamente esse todo, torna-se necessário passar à análise: sendo a população composta de classes sociais, é preciso analisá-las; mas isto só é possível analisando-se o trabalho assalariado e o capital; o capital, por sua vez, só pode ser compreendido adequadamente, através da análise do seu oposto, o trabalho assalariado, sendo que a relação entre ambos é mediada pelo valor, isto é, pelo valor de troca que, juntamente com o valor de uso, compõe a mercadoria; por sua vez, a troca entre mercadorias é mediada, no mercado, pelo equivalente geral do valor das mercadorias que é o dinheiro, mediante o qual é estabelecido o preço das mercadorias. Partiu-se da população (a representação caótica do todo, verificou-se a necessidade de analisar as classes sociais e essa análise conduziu, através de decomposições sucessivas, de abstrações cada 
vez mais sutis ("cada vez mais tênues"), às categorias mais simples, às determinações mais simples, isto é, ao valor que mediatiza a troca de mercadorias e mediatiza a venda da força de trabalho.

Mas o pensamento não encerra aí seu percurso. Ele agora terá que fazer o caminho inverso, isto é ascender da abstração mais simples à complexidade do conjunto que foi representado, inicialmente, de forma caótica. O trabalho analítico com as categorias mais simples e abstratas seguirá agora o percurso do progressivo enriquecimento da teoria interpretativa da realidade, até atingir novamente o todo que foi o ponto de partida, só que esse todo já não mais se apresenta ao pensamento como uma representação caótica, mas como "uma rica totalidade de determinações e relações diversas". O concreto é, assim, reproduzido pelo pensamento científico, que reconstrói, no plano intelectual, a complexidade das relações que compõem o campo da realidade que constitui o objeto de pesquisa.

Essas considerações de Marx são da maior importância para as ciências humanas nos dias de hoje se considerarmos que muitos pesquisadores rejeitam a perspectiva da totalidade, limitando-se ao micro, ao caso isolado, ao particular transformado em única instância real, sendo que por vezes isso é justificado como tentativa de dar conta da riqueza do caso singular, riqueza essa que esses pesquisadores afirmam ser perdida em todas as tentativas de visão totalizadora do real. Outras vezes esses pesquisadores não chegam propriamente a negar a necessidade da compreensão do todo, mas tal compreensão é postergada a estudos futuros que porventura venham a ser desenvolvidos por alguém. É como se, de miIhares de estudos microscópicos e fragmentários, pudesse surgir, por um passe de mágica, uma visão articulada do todo. Se a visão do todo que dirige essas pesquisas do caso singular em si mesmo são dirigidas pela representação caótica do todo, o fato é que elas não são capazes de realizar aquilo a que se propõem, isto é, captar a riqueza do singular justamente porque o singular só pode ser entendido em toda sua riqueza quando visto como parte das relações que compõem o todo. Esse nos parece ser um dos principais problemas de boa parte daquilo que no campo da pesquisa em educação é chamado de "metodologias qualitativas" (expressão, aliás, vaga e pouco esclarecedora), na medida em que tais metodologias têm gerado uma enorme quantidade de dissertações e teses que, com raras exceções, pouco ou nada acrescentam ao processo de compreensão do concreto enquanto uma rica totalidade com múltiplas determinações e relações diversas. Tais trabalhos partem de uma visão caótica do todo e mal chegam à elaboração de algumas categorias analíticas. 
A seguir, Marx afirma que o primeiro caminho (da representação caótica às abstrações mais simples) foi aquele historicamente percorrido pelos estudos econômicos no início dessa ciência. Marx (1978, pp. 116-117) diz então que o último caminho "é manifestamente o método científico correto", isto é, o concreto só pode ser adequadamente captado pelo pensamento não enquanto ponto de partida, mas enquanto ponto de chegada, enquanto síntese:

O concreto é concreto porque é a síntese de muitas determinações, isto é, unidade do diverso. Por isso o concreto aparece no pensamento como o processo da síntese, como resultado, não como ponto de partida, ainda que seja o ponto de partida efetivo e, portanto, o ponto de partida também da intuição e da representação. No primeiro método, a representação plena volatiliza-se em determinações abstratas, no segundo, as determinações abstratas conduzem à reprodução do concreto por meio do pensamento. Por isso é que Hegel caiu na ilusão de conceber o real como resultado do pensamento que se sintetiza em si, que se aprofunda em si, e se move por si mesmo; enquanto que o método que consiste em elevar-se do abstrato ao concreto não é senão a maneira de proceder do pensamento para se apropriar do concreto, para reproduzi-lo como concreto pensado. Mas este não é de modo nenhum o processo da gênese do próprio concreto. A mais simples categoria econômica, suponhamos, por exemplo, o valor de troca, pressupõe a população, uma população produzindo em determinadas condições e também certos tipos de famílias, de comunidades ou Estados. O valor de troca nunca poderia existir de outro modo senão como relação unilateral, abstrata de um todo vivo e concreto. (grifos no original)

Nos tempos atuais, nos quais intelectuais pós-modernos e construtivistas rejeitam a idéia de que o conhecimento seja a reprodução da realidade pelo pensamento, por considerarem tal idéia positivista e mecanicista, fazemos questão de ressaltar que na passagem acima citada o conhecimento é explicitamente entendido como apropriação da realidade objetiva, com reprodução dessa realidade no pensamento, isto é, a epistemologia de Marx é materialista e dialética, o concreto pensado é a apropriação dialética do concreto real através da mediação da análise, mediação do abstrato. Não há margem para qualquer tipo de relativismo subjetivista na epistemologia marxiana. 
Marx esclarece, na passagem acima, que o caminho das categorias mais simples, abstratas e unilaterais para a complexidade e concreticidade do todo é o caminho do pensamento e não da realidade, pois nesta as categorias simples só têm existência no interior de um todo já existente. Esse esclarecimento é importante por várias razões. Em primeiro lugar, porque previne contra as ilusões idealistas, que identificam os percursos do pensamento e do conhecimento com os percursos da realidade a ser conhecida. Em segundo lugar, porque também previne contra os reducionismos no campo epistemológico, mostrando que o conhecimento científico de uma dada realidade humana não pode ser alcançado sem a mediação do árduo processo de elaboração de abstrações e de reconstrução, no pensamento, das múltiplas relações que compõem o todo.

O segundo aspecto importante na passagem de Marx acima citada e que traz contribuições à análise que aqui desenvolvemos diz respeito à relação entre as unidades e o todo do qual elas fazem parte. Ao mostrar que as unidades não pré-existem ao todo, ou seja, que este não é o resultado de relações entre partes que já existiriam de forma autônoma e independente, Marx nos fornece uma preciosa indicação metodológica para a crítica às concepções a-históricas da relação entre indivíduo e sociedade. A complexidade das relações sociais não pode ser deduzida de características pretensamente existentes em todo indivíduo humano, nem mesmo deduzida diretamente das relações do tipo face to face. Tem sido muito freqüente nos estudos educacionais a interpretação de que considerar o indivíduo como um ser social seria sinônimo de considerar as relações face to face, isto é, as relações imediatas entre dois indivíduos. É claro que não estamos desconsiderando a importância dessas relações na formação da individualidade. Mas o que não concordamos é com a redução da socialidade a essas relações, até porque quando ocorre essa redução, ela acaba atingindo a própria interpretação das relações diretas entre indivíduos, que acabam sendo vistas de forma idealizada. Os estudos no campo da educação e, mais especificamente, no campo da psicologia da educação, que reduzem a socialidade humana aos desdobramentos de características individuais ou de relações diretas entre dois indivíduos, seguem a mesma linha de raciocínio dos economistas clássicos, criticados por Marx, que partiam das ações individuais ou das relações diretas entre dois indivíduos para, então, construírem sua visão da sociedade como um todo. Para esses economistas, o percurso percorrido pelo seu pensamento correspondia ao percurso social e histórico. 
Após analisar os dois caminhos do pensamento, isto é, da representação caótica do todo às abstrações e destas ao todo enquanto síntese de múltiplas relações e determinações, Marx chama a atenção para o fato de que não são os conceitos, isto é, as abstrações que, em si e por si mesmos, produziriam a mencionada síntese, de maneira totalmente independente da realidade social objetiva e do sujeito real (ou sujeitos reais). Marx está aí fazendo a crítica a todo tipo de idealismo que trate os conceitos e seu desenvolvimento como algo desvinculado dos sujeitos humanos reais, histórica e socialmente situados. Trata-se aqui da mesma questão tão amplamente tratada por Marx \& Engels (1993, pp. 36-37) em $A$ ideologia alemã, isto é, que os homens constróem suas representações mentais da realidade a partir da prática social concreta, vale dizer, a partir das necessidades objetivamente postas pela existência social:

\begin{abstract}
Os homens são produtores de suas representações, suas idéias, etc., mas os homens reais e ativos, tal como se acham condicionados por um determinado desenvolvimento de suas forças produtivas e pelo intercâmbio que a ele corresponde até chegar às suas formações mais amplas. A consciência jamais pode ser outra coisa que o ser consciente, e o ser dos homens é o seu processo de vida real.
\end{abstract}

Como vimos, em "O método da Economia Política", Marx defende dois princípios materialistas, anti-idealistas. O primeiro é o de que o concreto real e objetivo, com toda sua complexidade, existe antes do pensamento realizar o movimento de sua reprodução ideal e continua a existir durante essa reprodução, "em sua autonomia fora do cérebro, isto é, na medida em que o cérebro não se comporta se não especulativamente, teoricamente" (Marx 1978, p. 117). É claro que o pensamento que reproduz idealmente o real acaba por nele interferir no momento em que os sujeitos passem da atividade teórica para a intervenção transformadora da realidade. O segundo princípio é o de que o processo de elaboração da síntese do todo no pensamento é um processo desenvolvido por indivíduos historicamente situados, indivíduos concretos, processo de conhecimento esse que consiste na "elaboração da intuição e da representação em conceitos" (Marx 1978, p. 117). Assim como no plano da realidade objetiva, as categorias simples, abstratas e unilaterais não podem existir anterior e independentemente do todo, também no plano do pensamento, a representação caótica é o ponto de partida 
para o trabalho analítico que supera essa representação pela elaboração das categorias abstratas, as categorias simples.

$\mathrm{Na}$ seqüência de sua exposição, Marx formula uma questão sobre a relação entre gênese da realidade objetiva e gênese do pensamento. A questão é a seguinte: "estas categorias simples não possuem também uma existência independente histórica ou natural anterior às categorias mais concretas?" (Marx 1978, p. 117). Antes de mais nada é necessário lembrar algo que mencionamos no início deste item: a análise de Marx focaliza as categorias enquanto movimento do pensamento e enquanto movimento da realidade objetiva, isto é, a análise dos processos de conhecimento e de pensamento fundamenta-se, em Marx, numa concepção materialista, segundo a qual o movimento das categorias no pensamento é a expressão dos movimentos da realidade objetiva, exterior a esse pensamento. Embora em determinados momentos de seu texto Marx possa utilizar o termo "categoria" limitado ao significado de categorias do pensamento, mesmo nesses momentos Marx nunca perde de vista que as categorias do pensamento expressam movimentos da realidade objetiva. A pergunta acima apresentada, formulada por Marx, pode ser traduzida da seguinte maneira: o processo histórico de desenvolvimento das sociedades seguiria o mesmo percurso do processo de conhecimento, isto é, das categorias simples às mais complexas, das categorias unilaterais às multilaterais? $\mathrm{A}$ resposta dada por Marx é "depende", ou seja, não existe uma resposta única, uma fórmula única para responder a essa questão. Por um lado, ou melhor, num certo sentido, seria possível afirmar-se que o processo histórico caminha do simples ao complexo:

“... as categorias simples são a expressão de relações nas quais o concreto pouco desenvolvido pode ter se realizado sem haver estabelecido ainda a relação ou o relacionamento mais complexo que se acha expresso mentalmente na categoria mais concreta, enquanto o concreto mais desenvolvido conserva a mesma categoria como uma relação subordinada. $O$ dinheiro pode existir, e existiu historicamente, antes que existisse o capital, antes que existissem os bancos, antes que existisse o trabalho assalariado. Deste ponto de vista, pode-se dizer que a categoria mais simples pode exprimir relações dominantes de um todo menos desenvolvido, ou relações subordinadas de um todo mais desenvolvido, relações que já existiam antes que o todo tivesse se desenvolvido, no sentido que se expressa em uma categoria mais concreta. 
Nesta medida, o curso do pensamento abstrato que se eleva do mais simples ao complexo corresponde ao processo histórico efetivo. (Marx 1978, p. 118)

Para acompanhar o raciocínio de Marx, é necessário não perder de vista os significados que ele atribui às expressões "categorias abstratas" e "categorias concretas". As categorias abstratas são relações mais simples, unilaterais, parciais, enquanto que as categorias concretas são mais complexas, mais ricas e multilaterais. O dinheiro, enquanto categoria mais simples, unilateral e abstrata, existiu antes que existissem outras categorias mais complexas como o capital, os bancos e o trabalho assalariado. Assim, uma categoria mais simples, isto é, mais abstrata, pode ter desempenhado um papel dominante enquanto pertencia a um todo menos desenvolvido e, posteriormente, ter desempenhado um papel subordinado ao pertencer a um todo mais desenvolvido, expresso por uma categoria mais concreta. Portanto, nesse caso, o curso do pensamento, que se eleva do abstrato ao concreto, isto é, do simples ao conplexo, é o mesmo caminho percorrido pelo processo histórico.

Mas nem sempre existe essa correspondência, pois nem sempre as categorias mais simples precedem, do ponto de vista histórico, as categorias mais complexas. Certas formas desenvolvidas de economia, como a cooperação e a divisão do trabalho existiram, segundo Marx, em determinadas sociedades nas quais uma categoria tão simples como o dinheiro não existia. O exemplo do dinheiro é também empregado por Marx para ilustrar o fato de que uma categoria simples muda seu significado e sua importância na dinâmica social à medida em que o todo concreto da sociedade se modifique, com o transcorrer do processo histórico. Em outras palavras, o próprio desenvolvimento da categoria simples pode estar condicionado ao desenvolvido das categorias mais complexas, mais concretas. Marx (1978, p. 118) explica que:

... embora o dinheiro tenha, muito cedo e por toda parte, desempenhado um papel, não assume papel de elemento dominante na Antigüidade, senão de modo unilateral e em determinadas nações - as nações comerciais. E mesmo na Antigüidade mais culta, entre os gregos e os romanos, não atinge seu completo desenvolvimento, que se pressupõe existir na moderna sociedade burguesa, a não ser no período de sua dissolução. Essa categoria, que é no entan- 
to bem simples, só aparece portanto historicamente com todo o seu vigor nos Estados mais desenvolvidos da sociedade. E o dinheiro não entrava de modo nenhum em todas as relações econômicas, assim, no Império Romano, na época de seu perfeito desenvolvimento, permaneceram como fundamentais o imposto e as entregas em produtos. O sistema do dinheiro, propriamente dito, encontrava-se completamente desenvolvido apenas no exército, e jamais atingiu a totalidade do trabalho. De modo que, embora a categoria mais simples possa ter existido historicamente antes da mais concreta, pode precisamente pertencer em seu pleno desenvolvimento, intensivo e extensivo, a formas complexas de sociedade, enquanto que a categoria mais concreta já se achava plenamente desenvolvida em uma forma de sociedade menos avançada.

Também pode ocorrer historicamente o processo pelo qual uma categoria mais concreta vai se tornando uma categoria mais abstrata, uma categoria mais complexa vai se tornando mais simples. Para exemplificar isso, Marx analisa a evolução da categoria trabalho, enquanto categoria do pensamento econômico e também enquanto categoria da realidade econômica. Nessa análise, Marx mostra o processo de transformação do trabalho em uma abstração cada vez mais simples até se constituir em trabalho em geral, em trabalho abstrato, em força de trabalho em geral. O trabalho é focalizado enquanto categoria da economia política, isto é, categoria do pensamento científico e enquanto categoria da realidade econômica objetiva. Marx mostra que, como realidade objetiva, no capitalismo, o trabalho se caracteriza não por seu conteúdo concreto, mas por ser trabalho em geral, trabalho abstrato. Assim, o trabalhador também passa a ter seu ser enquanto trabalhador definido não pelo conteúdo concreto do trabalho que ele venha a realizar, mas pela capacidade de trabalho em geral. $O$ trabalhador torna-se trabalhador em geral, trabalhador abstrato. O capitalismo opera, dessa forma, o esvaziamento dos indivíduos, transformando-os em indivíduos abstratos.

Como categoria do pensamento, embora a idéia do trabalho em geral há muito existisse para o pensamento humano, foi necessária uma evolução do pensamento econômico para que se considerasse a produção da riqueza como resultado do trabalho em geral e não como resultado de algum tipo específico de trabalho, como o trabalho comercial, agrícola, industrial etc. Essa evolução do pensamento econômico é caracterizada por Marx como passando do monetarismo para o mercantilismo e deste para a 
fisiocracia, até chegar, finalmente, em Adam Smith, à idéia do trabalho em geral. O monetarismo situava a riqueza não no trabalho humano, mas no objeto em si mesmo, no caso, no dinheiro. O mercantilismo realizou o primeiro avanço ao considerar a produção da riqueza como resultante do trabalho humano, ou seja, o trabalho mercantil. Mas como o comércio era visto como um meio para a obtenção de dinheiro, a riqueza ainda era considerada uma propriedade do objeto, a ser buscado através da atividade mercantil. A fisiocracia avançou de forma significativa porque defendeu que a riqueza é produzida pelo trabalho agrícola, sendo constituída pelo produto em geral desse trabalho. Assim, a riqueza já não era mais vista na forma particular de um tipo de produto, no caso o dinheiro. Mas a fisiocracia ainda limitava a riqueza aos produtos de um tipo específico de trabalho. O passo decisivo foi dado por Adam Smith:

Um enorme progresso se deve a Adam Smith, que rejeitou toda determinação particular da atividade criadora de riqueza, considerando apenas o trabalho puro e simples, isto é, nem o trabalho industrial nem o trabalho comercial, nem o trabalho agrícola, mas todas essas formas de trabalho. Com a generalidade abstrata da atividade criadora de riqueza, igualmente se manifesta então a generalidade do objeto determinador da riqueza, o produto em absoluto, ou ainda, o trabalho em geral, mas enquanto trabalho passado, objetivado. (Marx 1978, p. 119)

Poderia parecer, à primeira vista, que "se teria encontrado unicamente a relação abstrata mais simples e mais antiga em que entram os homens em qualquer forma de sociedade, enquanto produtores" (idem, p. 119). Marx afirma, entretanto, que tal conclusão é correta em certo sentido mas não em outro. A produção material humana sempre dependeu, de certa forma, do trabalho. É possível afirmar que a riqueza não pode existir sem o trabalho e que o trabalho humano em geral é a fonte de criação da riqueza humana. Nesse sentido, pode-se afirmar que os economistas descobriram uma relação simples e antiga que sempre existiu. Mas esse grau de generalidade do raciocínio nada expressa sobre o processo histórico de desenvolvimento da produção da riqueza, tampouco explica o processo histórico de desenvolvimento da teoria econômica. $O$ fato de que o trabalho abstrato seja o gerador da riqueza não significa que tanto objetiva como subjetivamente o trabalho nesse grau de abstração estivesse dado no início do processo histórico. Marx (1978, p. 119) mostra que, ao contrário, esse trabalho abstrato é 
produto de uma sociedade mais complexa, na qual existe uma diversidade maior de trabalhos concretos:

\begin{abstract}
A indiferença em relação ao gênero de trabalho determinado pressupõe uma totalidade muito desenvolvida de gêneros de trabalho efetivos, nenhum dos quais domina os demais. Tampouco se produzem as abstrações mais gerais senão onde existe o desenvolvimento concreto mais rico, onde um aparece como comum a muitos. Então já não pode ser pensado somente sob uma forma particular. Por outro lado, essa abstração do trabalho em geral não é apenas o resultado intelectual de uma totalidade concreta de trabalhos. A indiferença em relação ao trabalho determinado corresponde a uma forma de sociedade na qual os indivíduos podem passar com facilidade de um trabalho a outro e na qual o gênero determinado de trabalho é fortuito, e, portanto, é-lhes indiferente. Neste caso o trabalho se converteu não só como categoria, mas na efetividade em um meio de produzir riqueza em geral, deixando, como determinação, de se confundir com o indivíduo em sua particularidade.
\end{abstract}

Marx cita então como exemplo os Estados Unidos, onde o capitalismo se apresentava na sua forma mais desenvolvida. Nesse país, o trabaIho enquanto abstração, enquanto trabalho em geral, apresentava-se pela primeira vez na história como realidade objetiva, pois o trabalhador não mais se caracterizava por realizar um tipo particular de trabalho, mas sim por realizar o trabalho em geral, por possuir uma força de trabalho em geral.

Somente no capitalismo o trabalho pode existir em sua forma mais abstrata, enquanto indiferença em relação aos tipos particulares de trabaIho e aos produtos particulares do trabalho, tornando-se importante apenas o trabalho em geral, tanto o acumulado, objetivado no capital, como o trabalho vivo, a força de trabalho do indivíduo trabalhador, enquanto força de trabalho abstrata, força de trabalho em geral. Da mesma forma, foi preciso que essa realidade existisse para que os economistas formulassem a concepção da riqueza enquanto trabalho em geral, trabalho abstratamente concebido. Assim, o trabalho, tanto na realidade sócio-econômica como na ciência (isto é, a economia política), mostrou-se em sua forma mais abstrata não no início da história mas apenas com o surgimento do capitalismo.

Neste ponto a análise de Marx das relações históricas entre as categorias abstratas e as categorias concretas leva à formulação da fa- 
mosa tese marxiana acerca das relações entre o lógico e o histórico: a análise da lógica de um determinado fenômeno na sua forma mais desenvolvida é a chave para a análise do processo histórico de desenvolvimento desse fenômeno:

A sociedade burguesa é a organização histórica mais desenvolvida, mais diferenciada da produção. As categorias que exprimem suas relações, a compreensão de sua própria articulação, permitem penetrar na articulação e nas relações de produção de todas as formas de sociedades desaparecidas, sobre cujas ruínas e elementos se acha edificada, e cujos vestígios, não ultrapassados ainda, leva de arrastão, desenvolvendo tudo que fora antes apenas indicado que toma assim toda a sua significação etc. A anatomia do homem é a chave da anatomia do macaco. O que nas espécies animais inferiores indica uma forma superior não pode, ao contrário, ser compreendido senão quando se conhece a forma superior. A economia burguesa fornece a chave da economia da antigüidade etc. Porém, não conforme o método dos economistas que fazem desaparecer todas as diferenças históricas e vêem a forma burguesa em todas as formas de sociedade. (Marx 1978, p. 120)

O fato de Marx empregar uma metáfora biológica, a qual faz referência à evolução das espécies, do macaco ao homem, não significa que Marx analisasse o processo histórico numa perspectiva evolucionista linear nem mesmo numa perspectiva teleológica da história. A história para Marx não persegue uma meta estabelecida previamente por alguém ou por algo. A existência da forma burguesa de sociedade não estava pré-estabelecida já no início da história, ela é um produto do devenir histórico. Sendo produto de um processo histórico, a sociedade burguesa carrega em si mesma as marcas desse processo. Os economistas são criticados por Marx por acharem que as características próprias da sociedade burguesa, próprias do capitalismo, já estavam presentes nas formas mais primitivas de vida social. Dessa forma os economistas concebem de maneira totalmente a-histórica o capitalismo, o que constitui um procedimento ideológico de eternização das relações capitalistas de produção e de naturalização do mercado. Mas também fica evidente nas palavras de Marx que, mesmo sem adotar uma posição evolucionista ingênua, ele via a história como um processo de desenvolvimento. Essa é uma idéia atualmente muito contestada pelos pós-modernos e mesmo por certos neomarxistas. Embora não haja aqui espaço para entrar em detalhes sobre a questão da idéia de desenvolvimento e de pro- 
gresso na perspectiva dialética do materialismo histórico de Marx, assinalamos que consideramos um grande equívoco contrapor a idéia de desenvolvimento a uma visão crítica da história, como se esta tivesse que necessariamente negar o desenvolvimento e o progresso. Esse equívoco decorre de um tipo de relativismo que produz conseqüências fortemente reacionárias. Não é demais citar aqui uma passagem de Gramsci sobre essa questão:

É indubitável que o progresso foi uma ideologia democrática, bem como é também indubitável que tenha servido politicamente na formação dos modernos estados constitucionais etc. Igualmente é incontestável que ela hoje já não mais está em seu auge. Mas em que sentido? Não no sentido de que se tenha perdido a fé na possibilidade de dominar racionalmente a natureza e o acaso, mas no sentido "democrático"; ou seja, de que os "portadores" oficiais do progresso tornaram-se incapazes deste domínio, já que suscitaram forças destruidoras atuais tão perigosas e angustiantes quanto as do passado [...], tais como as "crises", o desemprego etc. A crise da idéia de progresso, portanto, não é uma crise da idéia em si, mas uma crise dos portadores dessa idéia, os quais se tornaram, eles mesmos, uma "natureza" que deve ser dominada. Os ataques à idéia de progresso, nessa situação, são muito interessados e tendenciosos. (1995, p. 45)

É óbvio que a concordância com a afirmação de Marx, de que a compreensão da lógica da sociedade burguesa permite compreender as sociedades que a precederam, exige a aceitação do pressuposto de que "a sociedade burguesa é a organização histórica mais desenvolvida" e, conseqüentemente, da idéia de desenvolvimento histórico, de progresso histórico. Para Marx, a despeito do capitalismo ser uma sociedade geradora das mais profundas formas de alienação já existentes, a sociedade burguesa constitui-se num avanço em relação às sociedades precedentes por criar as condições para a passagem ao socialismo.

Em termos metodológicos, a afirmação de que "a anatomia do homem é a chave da anatomia do macaco" significa que a pesquisa deve partir da fase mais desenvolvida do objeto investigado para então analisar sua gênese e, depois da análise dessa gênese, retornar ao ponto de partida, isto é, à fase mais evoluída, agora compreendida de forma ainda mais concreta, iluminada pela análise histórica. Mas essa análise, apoiada na dialética entre o lógico e o histórico, só se realiza 
de forma verdadeiramente esclarecedora do objeto investigado se for apoiada numa perspectiva crítica, isto é, se for realizada a crítica daquilo que esteja sendo tomado como a forma mais desenvolvida. Se não houver essa perspectiva crítica, a análise histórica torna-se um recurso de legitimação da situação atual, deixando de ser uma forma de compreender melhor as possibilidades de transformação dessa situação. Marx tinha clareza quanto a isso e chamava a atenção para o fato de que a perspectiva crítica em relação à sociedade burguesa deveria fazer com que o pesquisador tomasse as devidas cautelas para não adotar uma posição evolucionista ingênua em sua análise histórica:

Como, além disso, a própria sociedade burguesa é apenas uma forma opositiva do desenvolvimento, certas relações pertencentes a formas anteriores nela só poderão ser novamente encontradas quando completamente atrofiadas, ou mesmo disfarçadas; por exemplo, a propriedade comunal. Se é certo, portanto, que as categorias da economia burguesa possuem o caráter de verdade para todas as demais formas de sociedade, não se deve tomar isso senão "cum grano salis" [em sentido bem determinado]. Podem ser desenvolvidas, atrofiadas, caricaturadas, mas sempre essencialmente distintas. $O$ chamado desenvolvimento histórico repousa em geral sobre o fato de a última forma considerar as formas passadas como etapas que levam a seu próprio grau de desenvolvimento, e dado que ela raramente é capaz de fazer a sua própria crítica, e isso em condições bem determinadas, concebe-os sempre sob um aspecto unilateral. A religião cristã só pode ajudar a compreender objetivamente as mitologias anteriores depois de ter feito, até certo grau, por assim dizer, dynamei, a sua própria crítica. Igualmente, a economia burguesa só conseguiu compreender as sociedades feudal, antiga, oriental, quando começou a autocrítica da sociedade burguesa. Na medida em que a economia burguesa, criando uma nova mitologia, não se identificou pura e simplesmente com o passado, a crítica que fez às sociedades anteriores, em particular à sociedade feudal, contra a qual tinha ainda que lutar diretamente, assemelhou-se à crítica do paganismo feita pelo cristianismo, ou à do catolicismo feita pela religião protestante. (1978, pp. 120-121)

Para concluir sua exposição sobre a questão metodológica, Marx chama a atenção para o fato de que, embora o conhecimento científico caminhe do abstrato ao concreto, da parte para o todo, é preciso nunca es- 
quecer que na realidade objetiva o todo já existe antes que ele seja reproduzido no plano do pensamento. Isso tem implicações metodológicas decisivas, pois, sendo esse todo possuidor de certas características que o definem e o diferenciam de outros que o precederam, essas características também determinam o ser das partes. Em outras palavras, ainda que o pensamento se detenha em uma parte do todo, jamais deve ser esquecido que essa parte não tem existência em si e por si mesma e também não dever ser esquecido que essa parte assume características distintas, dependendo de a qual todo ela pertença. Vejamos então como Marx expõe essa questão. De início, ele alerta para o fato de que o objeto já existe antes de ser tratado como objeto do conhecimento científico:

Do mesmo modo que toda ciência histórica e social em geral é preciso ter sempre em conta, a propósito do curso das categorias econômicas, que o sujeito, nesse caso a sociedade burguesa moderna, está dado tanto na realidade efetiva como no cérebro; que as categorias exprimem portanto formas de modos de ser, determinações de existência, freqüentemente aspectos isolados desta sociedade determinada, deste sujeito, e que, por conseguinte, esta sociedade de maneira nenhuma se inicia, inclusive do ponto de vista científico, somente a partir do momento em que se trata dela como tal. (Marx 1978, p. 121)

Ora, essa observação é da maior importância pois quando o conhecimento científico parte da premissa de que o objeto já existe enquanto um todo com determinadas características, a lógica do percurso que vai do abstrato ao concreto não pode tomar qualquer abstração como ponto de partida, nem mesmo iludir-se com aquilo que pareça ser o ponto de partida mais natural:

Nada parece mais natural, por exemplo, do que começar pela renda da terra, pela propriedade fundiária, dado que está ligada à terra, fonte de produção de qualquer sociedade que atingiu um certo grau de estabilidade - à agricultura. Ora, nada seria mais errado. $\mathrm{Em}$ todas as formas de sociedade se encontra uma produção determinada, superior a todas as demais, e cuja situação aponta sua posição e influência sobre as outras. É uma luz universal de que se embebem todas as cores, e que as modifica em sua particularidade. (Marx 1978, pp. 121) 
Embora a agricultura seja, a partir de determinado estágio de desenvolvimento, a forma mais "natural" de produção da existência humana, não significa que seja também o melhor ponto de partida para compreender a produção na sociedade capitalista:

Na sociedade burguesa é o contrário. A agricultura transforma-se mais e mais em simples ramo da indústria e é dominada completamente pelo capital. A mesma coisa ocorre com a renda da terra. Em todas em que domina a propriedade fundiária, a relação com a natureza é ainda preponderante. Naquelas em que domina o capital, o que prevalece é o elemento produzido social e historicamente. Não se compreende a renda da terra sem o capital, entretanto compreende-se o capital sem a renda da terra. Deve constituir o ponto inicial e o ponto final a ser desenvolvido antes da propriedade da terra. Depois de considerar particularmente um e outro, deve-se estudar sua relação recíproca. (Marx 1978, pp. 121-122)

Aqui vale a pena fazer menção ao fato de que, na psicologia sóciohistórica de Vigotski e seguidores, a análise de funções e faculdades psíquicas tinha por pressuposto que o desenvolvimento de cada função psíquica não é autônomo, mas sim depende de um todo do qual ela é parte. Citaremos dois exemplos. O primeiro é o de Vigotski, analisando o desenvolvimento da personalidade da criança e de sua concepção de mundo:

... o menor de qualquer avanço na esfera do desenvolvimento cultural consiste, como vimos, em que o homem domina os processos de seu próprio comportamento. Porém a premissa imprescindível para esse domínio é a formação da personalidade, de modo que o desenvolvimento de uma ou outra função depende e está sempre condicionado pelo desenvolvimento global da personalidade. (Vygotsky 1995, p. 329)

O segundo exemplo extraímos de Leontiev, mais especificamente de seu conceito de atividade principal que, de certa forma, aprimora a concepção de Vigotski exposta na passagem acima citada. Segundo Leontiev, "a atividade principal é então a atividade cujo desenvolvimento governa as mudanças mais importantes nos processos psíquicos e nos 
traços psicológicos da personalidade da criança, em um certo estágio de seu desenvolvimento" (Leontiev 1988, p. 65). Infelizmente não há espaço aqui para analisarmos a importância do conceito de atividade principal para a psicologia do desenvolvimento e para a educação.

Retomando o texto de Marx, ele conclui sua resposta à pergunta por ele mesmo formulada, acerca das relações entre o lógico e o histórico, ou seja, se a ordem seguida pelo pensamento científico no processo de construção teórica da compreensão de uma dada sociedade seria a mesma seguida pelo processo histórico:

\begin{abstract}
Seria, pois, impraticável e errôneo colocar as categorias econômicas na ordem segundo a qual tiveram historicamente uma ação determinante. A ordem em que se sucedem se acha determinada, ao contrário, pelo relacionamento que têm umas com as outras na sociedade burguesa, e que é precisamente o inverso do que parece ser uma relação natural, ou do que corresponde à série do desenvolvimento histórico. (Marx 1978, p. 122)
\end{abstract}

Assim, na dialética entre o lógico e o histórico, o pensamento humano analisa a lógica da fase mais desenvolvida do objeto e vai à história para compreender a gênese desse objeto e compreender as fases anteriores do processo histórico. Essa análise histórica, por sua vez, aprofunda a compreensão da fase mais desenvolvida, tornando ainda mais rica a reprodução do concreto pelo pensamento, reprodução essa que requer, como vimos, a mediação das abstrações.

Finalizando este item sobre o método dialético em Marx, podemos agora retomar a passagem do manuscrito de Vigotski, em que este afirma que a interação entre a criança, enquanto ser em desenvolvimento, e o adulto, enquanto ser desenvolvido, é a principal fonte impulsionadora do desenvolvimento cultural da criança, que Vigotski diferenciava do desenvolvimento orgânico. Para a psicologia e para a educação, a análise do desenvolvimento da criança precisa, portanto, partir do mais desenvolvido para o menos desenvolvido. Poderíamos afirmar que o adulto desenvolvido é a chave para a compreensão do desenvolvimento infantil. Mas também não podemos esquecer que esse desenvolvimento infantil se dá pela interação com o adulto já desenvolvido. Isso diferencia a ontogênese da filogênese, pois o desenvolvimento histórico do gênero humano partiu de si mesmo e não da interação com uma forma mais evoluída de ser. Já no 
caso do desenvolvimento cultural da criança, existe uma forma mais evoluída de ser que produz o desenvolvimento da forma menos evoluída. Isso torna extremamente complexa a análise do desenvolvimento infantil e põe no centro dessa análise a questão da educação, pois tal desenvolvimento é fruto do processo educativo. Nos limites deste artigo, não poderemos extrair todas as implicações dessa concepção, mas apresentaremos, no próximo item, a título de exemplificação dessas implicações, uma breve análise da questão do saber na educação escolar.

\section{A dialética do pensamento como reflexo da realidade objetiva e a questão do saber na educação escolar}

No livro Pedagogia histórico-crítica: primeiras aproximações, Dermeval Saviani expõe que a tarefa dessa pedagogia em relação à educação escolar implica:

a) Identificação das formas mais desenvolvidas em que se expressa o saber objetivo produzido historicamente, reconhecendo as condições de sua produção e compreendendo as suas principais manifestações, bem como as tendências atuais de transformação; b) Conversão do saber objetivo em saber escolar de modo a torná-lo assimilável pelos alunos no espaço e tempo escolares; c) Provimento dos meios necessários para que os alunos não apenas assimilem o saber objetivo enquanto resultado, mas apreendam o processo de sua produção bem como as tendências de sua transformação. (Saviani 1997, p. 14)

Nosso entendimento é o de que a psicologia vigotskiana fornece apoio a essa formulação de Saviani acerca da tarefa da pedagogia histórico-crítica no tocante à educação escolar. A análise que apresentamos nos itens anteriores deste artigo procurou evidenciar as relações entre a dialética em Vigotski e em Marx e acreditamos ter mostrado que tanto Marx como Vigotski não só defendiam que o saber é objetivo, isto é, que ele reflete a realidade objetivamente existente, como também defendiam que existe um processo de desenvolvimento do saber, o que resulta na existência de formas mais evoluídas do saber. Por fim, ficou evidente que tanto para Marx como para Vigotski, as formas mais desenvolvidas devem ser 
o ponto de partida para a compreensão das formas menos desenvolvidas. Assim como a concepção pedagógica de Dermeval Saviani, também a psicologia vigotskiana apoia-se no método dialético de Marx, em cujo âmbito não há margem nem para o evolucionismo ingênuo (seja no plano da história da organização social humana, seja no plano da história do conhecimento), nem para o relativismo que nega a existência de formas mais desenvolvidas de vida social e de conhecimento, nem, finalmente, para 0 subjetivismo que nega o conhecimento enquanto apropriação da realidade objetiva pelo pensamento. Talvez não seja demais explicitar que ao ressaltar esses aspectos da epistemologia de Marx, da psicologia de Vigotski e da pedagogia de Saviani, estamos intencionalmente nos contrapondo à tônica dominante nos ideários pedagógicos contemporâneos, que concebem o processo educativo como um processo de interação entre significados subjetivos e individuais em oposição à transmissão de um saber objetivo socialmente construído e que condenam como autoritária, etnocêntrica, falocêntrica e racista a defesa de que existam saberes mais desenvolvidos, que passaram a ter validade universal para o gênero humano e que devam ser transmitidos pela escola.

A título tanto de conclusão deste artigo como de incentivo ao debate sobre essa questão, analisaremos algumas considerações de Vigotski acerca das relações entre pensamento e realidade objetiva.

No volume IV das Obras escolhidas, ao analisar "O desenvolvimento das funções psíquicas superiores na idade de transição", Vigotski aborda, a certa altura, o princípio do pensamento como reflexo da realidade objetiva, mostrando que é um equívoco pensar que esse princípio implica em passividade do sujeito perante essa realidade:

Quando se estuda o reflexo, sem considerá-lo em movimento, pode dizer-se que se uma ou outra operação, por exemplo, a linguagem ou a consciência, reflete algum processo que se desenvolve objetivamente, neste caso a linguagem não pode cumprir nenhuma função essencial, já que o reflexo em um espelho não pode modificar o destino do objeto refletido. Porém se tomamos um fenômeno em desenvolvimento, veremos que graças ao reflexo dos nexos objetivos e, em particular, ao autoreflexo da prática humana no pensamento verbal do ser humano, surge sua autoconsciência e sua possibilidade de dirigir conscientemente suas ações. "A consciência, em geral, reflete a existência. Esta é a tese de todo o materialismo" (V. I. Lénine, Obras completas, t. 18, p. 343, edição russa). 
"O domínio da natureza que se revela na prática da humanidade, é o resultado do reflexo objetivamente fiel dos fenômenos e processos da natureza na mente humana, e demonstra que esse reflexo (no marco da prática) é uma verdade objetiva, absoluta, eterna" (ibidem, p. 198). (Vygotsky 1996b, p. 164)

Essas citações que Vigotski faz de Lénine se encontram, como nos é informado pelo próprio Vigotski, no tomo 18 das Obras Completas em russo, sendo portanto citações extraídas do livro Materialismo e empiriocriticismo: notas críticas sobre uma filosofia reacionária (Lénine 1982). Consideramos duplamente interessante citar essa passagem de Vigotski. Primeiro porque nela Vigotski mostra que, ao contrário do que afirmam os críticos do princípio do conhecimento como reflexo da realidade objetiva, esse reflexo é fundamental para que o indivíduo se torne sujeito de suas ações e para a construção de sua personalidade (lembramos que se trata de um texto no qual Vigotski aborda o período da adolescência e de um momento do texto no qual o psicólogo soviético focaliza o desenvolvimento da capacidade de autocontrole). O outro motivo é o fato de Vigotski estar citando uma obra de Lénine que, segundo alguns marxistas ocidentais, defenderia uma teoria do conhecimento não dialética, resvalando para uma epistemologia mecanicista e positivista. Assinalamos que vemos a necessidade de ser retomado o estudo desse livro, pois tais críticas nos parecem fortemente influenciadas por um espírito pós-moderno que acaba por negar a luta entre o idealismo e o materialismo. Note-se que todo o livro de Lénine foi escrito para mostrar que as tentativas de se encontrar uma terceira via ao materialismo e ao idealismo, bem como as tentativas de se decretar como superada a luta pelo materialismo e contra o idealismo, acabam resultando em defesas disfarçadas de posições idealistas e solipsistas. Esse é o caso das concepções de Ernest Mach (1838-1916) criticadas por Lénine, como também é o caso do pragmatismo, em suas várias vertentes.

O trecho citado, em Vigotski, não deixa margem para dúvidas quanto ao fato deste autor adotar o princípio do conhecimento enquanto reflexo, e que isso não significa, de modo algum, que Vigotski adota uma concepção do pensamento como algo passivo perante a realidade objetiva, nela incluída a ação do próprio sujeito pensante. Ao assumir o princípio do reflexo, Vigotski está assumindo a objetividade do conhecimento. Assim, podemos afirmar que a psicologia 
vigotskiana dá total respaldo a uma pedagogia na qual a escola deva ter como papel central possibilitar a apropriação do conhecimento objetivo pelos alunos.

Como vimos no texto de Marx, o reflexo da realidade objetiva no pensamento, isto é, a apropriação do concreto pelo pensamento se dá pela mediação das abstrações, pela mediação dos conceitos mais abstratos. O que aparentemente seria um afastamento da realidade concreta é, na verdade, o caminho para o conhecimento cada vez mais profundo dos processos essenciais da realidade objetiva. Vigotski via no desenvolvimento desse tipo de pensamento um dos momentos essenciais da passagem da infância à adolescência, por meio da formação do pensamento por conceitos.

Vigotski conhecia Os cadernos sobre a dialética de Hegel, nos quais Lénine fez suas anotações de estudo da filosofia hegeliana. Nessas anotações, Lénine abordou a questão da abstração e dos conceitos como processo de maior domínio da realidade pelo pensamento:

No fundo, Hegel tem toda a razão contra Kant. Ao elevar-se do concreto ao abstrato o pensamento não se afasta - se é verdadeiro (N.B.) (e Kant, como todos os filósofos, fala do pensamento verdadeiro) - da verdade, pois aproxima-se dela. As abstrações de matéria e de lei natural, a abstração de valor etc., numa palavra, todas as abstrações científicas (justas, sérias e não arbitrárias), refletem mais profundamente, mais exatamente e mais completamente a Natureza. Da intuição viva ao pensamento abstrato e deste à prática: eis o caminho dialético do conhecimento do verdadeiro, do conhecimento da realidade objetiva. (Lénine 1975, p. 95, as observações entre parênteses constam do original)

Mais adiante, Lénine volta à questão da importância da abstração e dos conceitos como apropriação da realidade objetiva pelo pensamento:

A formação dos conceitos (abstratos) e das operações com eles implica já a representação, a certeza, a consciência das leis objetivas e da conexão universal. Desligar a causalidade desta conexão é absurdo. Impossível negar a objetividade dos 
conceitos, a objetividade do universal no particular e no singular. Hegel estudou, portanto, muito mais profundamente do que Kant e outros, o reflexo dos movimentos do mundo objetivo no movimento dos conceitos. Do mesmo modo que a simples forma do valor, o ato isolado da troca de dada mercadoria por outra abarca já, numa forma não evoluída, todas as contradições fundamentais do capitalismo, assim como a mais simples generalização, a primeira e mais simples formação dos conceitos (opiniões, silogismos, etc.), significa o conhecimento cada vez mais profundo, pelo homem, do encadeamento universal objetivo. É aqui que se deve procurar o sentido verdadeiro, a significação e o papel da lógica de Hegel. (Lénine 1975, pp. 103-104)

No texto "O desenvolvimento das funções psíquicas superiores na idade de transição", Vigotski cita o trecho acima em apoio à sua tese de que a passagem ao pensamento por conceitos é o passo decisivo, na adolescência, para o desenvolvimento da personalidade e da concepção de mundo do indivíduo (cf. Vygotsky 1996b, p. 198).

Nessa concepção vigotskiana do desenvolvimento da personalidade através do conhecimento mais profundo da realidade objetiva, incluídas nesta as ações realizadas pelos seres humanos e pelo próprio indivíduo em desenvolvimento, evidencia-se a importância da educação escolar, da transmissão do saber objetivo pelo trabalho educativo na escola. Ao conseguir que o indivíduo se aproprie desse saber, convertendo-o em "órgão de sua individualidade" (segundo uma expressão de Marx), o trabalho educativo estará possibilitando que o indivíduo possa ir além dos conceitos cotidianos, possa ter esses conceitos superados por incorporação pelos conceitos científicos e assim possa conhecer de forma mais concreta, pela mediação das abstrações, a realidade da qual ele é parte ${ }^{9}$.

Esse processo é indispensável ao desenvolvimento da individualidade para-si, tal como a conceituamos no livro resultante de nossa tese de doutorado (Duarte 1993). E Vigotski tinha bastante clareza quanto à importância da passagem do em si ao para si no desenvolvimento do ser humano, isto é, no processo que vai da infância à idade adulta. Isso porque Vigotski tinha clareza quanto ao ponto de chegada do processo de desenvolvimento, tinha clareza de que a anatomia do homem é a chave da anatomia do macaco: 
A frase de J. J. Rousseau referente ao período de maturação sexual, de que o homem nasce duas vezes, primeiro para existir e depois para continuar a espécie, pode aplicar-se também ao desenvolvimento psicológico e cultural do adolescente. Tão somente então, ao chegar a esse ponto de viragem, começa o adolescente a prosseguir a vida da humanidade, a vida do gênero humano. Para expressar melhor a diferença entre a criança e o adolescente utilizaremos a tese de Hegel sobre a coisa em si e a coisa para si. Ele dizia que todas as coisas existem no começo em si, mas com isto a questão não se esgota e no processo de desenvolvimento a coisa se converte em coisa para si. O homem, dizia Hegel, é em si uma criança cuja tarefa não consiste em permanecer no abstrato e incompleto "em si", mas em ser também para si, isto é, converter-se em um ser livre e racional. Pois bem, essa transformação da criança do ser humano em si em adolescente - o ser humano para si - configura o conteúdo principal de toda a crise da idade de transição. (Vygotsky, 1996b, p. 200)

Essa passagem do ser humano em ser para si constitui, segundo nosso entendimento, a expressão maior da concepção do homem como um ser livre e universal contida na perspectiva de Marx acerca da sociedade comunista.

\section{Notas}

1. Vigotski 1991a, p. 391. Trata-se do texto "O significado histórico da crise da psicologia: uma investigação psicológica". Utilizaremos a edição em espanhol, publicada no primeiro volume das Obras escolhidas desse autor. Esse texto foi editado em português numa coletânea intitulada Teoria e método em psicologia (Vigotski, 1996a). Entretanto, não empregaremos aqui a edição em português porque, ao compará-la com o texto em espanhol, este pareceu-nos mais condizente com as idéias de Vigotski.

2. Na edição em português o final desse parágrafo fica sem sentido pois está assim escrito: "é o mesmo que o cristianismo sem Cristo ou o budismo sem Alá". (Vigotski, 1996a, p. 257)

3. Na edição em português o sentido do raciocínio de Vigotski é distorcido, pois lêse o seguinte: "é necessário conquistá-la para o marxismo, estudá-la empregando os meios da verdadeira metodologia". Ora, parece-nos muito mais condizente com o raciocínio de Vigotski que deva ser conquistado pelo marxismo o inconsciente, isto é, o objeto da psicanálise e não a própria psicanálise. 
4. Na edição em português (Vigotski 1996a, p. 417), essa frase inteira foi suprimida! Entendemos que falhas de digitação e revisão podem ocorrer. Mas a ausência de uma frase tão decisiva não é aceitável.

5. Vigotski (1991, p. 257-406).

6. Existe uma edição em português de Psicologia da arte, (Vigotski 1999), mas a edição em espanhol é mais completa por incluir um texto de Vigotski intitulado "A tragédia de Hamlet, príncipe da Dinamarca, de W. Shakespeare" e por apresentar um prólogo escrito por Leontiev, também excluído da edição em português.

7. Sobre as distorções do pensamento de Vigotski operadas pela tradução resumida do livro Pensamento e linguagem existente em português, veja-se nosso livro Vigotski e o "Aprender a Aprender": crítica às apropriações neoliberais e pós-modernas da teoria vigotskiana (Duarte 2000).

8. Vigotski (1996b, p.43): "Quando Vigotski escrevia seu livro, muitos autores qualificavam como transição toda a etapa da adolescência, utilizando esses termos como equivalentes, subentendendo a passagem da infância à idade adulta. Vigotski compartilhava esse ponto de vista." (nota da edição russa).

9. Analisamos o papel da educação escolar enquanto mediação, na formação dos indivíduos entre a esfera da vida cotidiana e as esferas não-cotidianas da prática social (ciência, arte, filosofia e política) em nosso livro Educação escolar, teoria do cotidiano e a Escola de Vigotski (Duarte 1996).

\section{Encaminhado para publicação em maio de 2000}

\section{The man anatomy is the key to the monkey anatomy: The dialectics in Vigotski and in Marx and the issue about objective knowledge in school education.}

ABSTRACT: Vygotsky, in his manuscript Concrete Human Psychology, asserts that the relationship ontogeny-philogeny in cultural development is different from the same relationship in organic development: the human fetus develops itself without an interection with a mature biotype, whereas in cultural development this interaction is the most important force for all development. Thus, this article analysis the relationship between the dialectics present in Vygotsky and in Marx, substantiated in methodological and epistemological reflexion done by Marx on the text whereby he asserts that "the human anatomy is the key for monkey anatomy". The conclusion of this article defends that Vygotsky's psychology supports a pedagogy which one appreciates the conduction of children to learn the highest objective knowledge produce by all mankind. 


\section{Bibliografia}

DUARTE, N. A individualidade para-si: contribuição a uma teoria histórico-social da formação do indivíduo. Campinas: Autores Associados, 1993.

. Educação escolar, teoria do cotidiano e a Escola de Vigotski. Campinas: Autores Associados, 1996.

.Vigotski e o "aprender a aprender": crítica às apropriações neoliberais e pós-modernas da teoria vigotskiana. Campinas: Autores Associados, 2000.

GRAMSCI, A. Concepção dialética da história. Rio de Janeiro: Civilização Brasileira, 10 ed., 1995.

LÉNINE, V. I. Os cadernos sobre a dialética de Hegel. Lisboa: Minerva, 1975. .Materialismo e empiriocriticismo. Lisboa: Avante, 1982.

LEONTIEV, A. N. O desenvolvimento do psiquismo. Lisboa: Livros Horizonte, 1978.

. "Uma contribuição à teoria do desenvolvimento da psique infantil". In: Vigotskil, L. S.; LURIA, A . R. \& LEONTIEV, A . N. (1988) - Linguagem, Desenvolvimento e Aprendizagem. São Paulo: Ícone \& EDUSP, 1988, p. 59-83.

MARX, K. Manuscritos econômico-filosóficos e outros textos escolhidos (Coleção Os pensadores). São Paulo: Abril Cultural, 1978.

. O capital - "Crítica da Economia Política", Volume I, Livro Primeiro: O Processo de Produção do Capital. São Paulo: Abril Cultural, 1983.

MARX, K. \& ENGELS, F. A ideologia alemã (Feuerbach). São Paulo: HUCITEC, 9 ${ }^{a}$ ed., 1993.

PIAGET, J. Seis estudos de psicologia. Rio de Janeiro: Forense Universitária, $20^{\underline{a}}$ ed., 1994.

SAVIANI, D. Pedagogia histórico-crítica: primeiras aproximações. Campinas: Autores Associados, 6르 ed., 1996.

VYGOTSKY, L. S. Psicología del arte. Barcelona: Barral, 1972. 
. Teoria e método em psicologia. São Paulo: Martins Fontes, 1996a.

. Psicologia da arte. São Paulo: Martins Fontes, 1999.

. Obras escogidas, tomo I. Madri: Visor e MEC, 1991.

. Obras escogidas, tomo II. Madri: Visor e MEC, 1993.

. Obras escogidas, tomo III. Madri: Visor e MEC, 1995.

. Obras escogidas, tomo IV. Madri: Visor e MEC1996b.

. "Concrete Human Psychology", Soviet Psychology, XXII

(2), 1989, pp. 53-77. 